special significance or even grandeur, so the recognition may sometimes amount to an attitude of awe or reverence. As such, a sense of wonder prompts reflective considerations about the place of mankind in the natural world and questions about whether 'the natural' is the sum total of the world, questions about what or who controls that world and about our individual destinies within it. Again, it would be hard to doubt that a sense of wonder has played a role in creative artistic responses to the world around us.

To approach something in wonder is to put yourself aside to some extent, to magnify the significance of the observed in relation to you who observe. The psychological importance of this is felt, for instance, when as a parent you contemplate your child; but also when you are struck by how experiences that you recognise in yourself belong also to other people - who, perhaps, respond to them as you would yourself like to respond to them (creatively, bravely, calmly, with insight) though you fear that in fact you could not. In this way, wonder is an important attitude ethically, reminding us that things, or people, or interests beyond ourselves are connected to us, but also have a claim upon us sometimes a higher claim than the mundane ones that normally see us through the working day. Literature peerlessly opens our eyes to wonder. I think the electrifying passage from The Magic Mountain with which I began exemplifies this perfectly, laying open to our gaze not only the literal but also the metaphorical wonder of our own physicality (Good God, it was the heart!... He looked into his own grave... the flesh in which he walked [was] disintegrated, annihilated, dissolved in vacant mist) in stunning yet sobering verbal apparitions.

Why is this clinically important? Those latter, ethical aspects are probably clearest, and apply quite straightforwardly to the praiseworthy list of 'attitudinal objectives' urged in Tomorrow's Doctors. To wonder at the fortitude of patients is, among other things, also to respect those patients. But a sense of wonder also invites us to incorporate gentleness, discretion, dignity and respect into that scientific curiosity which it is natural to feel towards so perplexing a phenomenon as the embodied, experiencing, human organism - who is also the patient. A lively and cultivated sense of wonder extends our capacity to be committed professionally to each successive individual, each particularised case of otherwise abstract and general disease categories and, moreover, stimulates a richly alert awareness of the diagnostic and therapeutic importance of easily missed variations in presentation and context. Above all, a sense of wonder wonder at this wondrous intersection, fusion, of 'meat' and 'point of view' - is the bedrock of recognising the medical privilege of intervening in frail human flesh and experience. Being aware of that privilege could brighten the darkest of clinical days in the course of a demanding career.

\section{References}

Charon, R., Brody, H., Clark, M. W., et al (1996) Literature and ethical medicine: five cases from common practice. Journal of Medicine and Philosophy, 21, 243-265.

Collier, J. A. B., Longmore, J. M. \& Hodgetts, T. J. (1995) Fame, fortune, medicine and art. In The Oxford Handbook of Clinical Specialities (4th edn) (eds J. A. B. Collier, J. M. Longmore \& T. J. Hodgetts), p. 413. Oxford: Oxford University Press.

Evans, M. (2002) Reflections on the humanities in medical education. Medical Education, 36, 506-507.

General Medical Council (1993) Tomorrow's Doctors: Recommendations on Undergraduate Medical Education. London: General Medical Council.

Mann, T. (1927) Der Zauberberg. Reprinted (1996) as The Magic Mountain (trans. H. Lowe-Porter). New York: Vintage Books.

McLellan, F. (1996) Why literature and medicine? Lancet, 348, 109-111.

Pickering, N. (1998) Imaginary restrictions. Journal of Medical Ethics, 24, 171-175.

Polanyi, M. (1958) Personal Knowledge: Towards a Post-critical Philosophy. Chicago, IL: University of Chicago Press.

Tolstoy, L. (1876) Anna Karenina. Reprinted (1954) as Anna Karenin (trans. R. Edmonds). Harmondsworth: Penguin.

Toulmin, S. (1993) Knowledge and art in the practice of medicine: clinical judgement and historical reconstruction. In Science, Technology and the Art of Medicine (eds C. Delkeskamp-Hayes \& M. A. Gardell Cutter), pp. 231-249. Dordrecht: Kluwer Academic Publishers.

\title{
INVITED COMMENTARY ON Roles for literature in medical education
}

I yield to no one in my regard for Advances in Psychiatric Treatment, but must admit that even in a journal of its quality, it is rare to find a paper that is an unalloyed joy to read. Evans's exploration of how literature can illuminate medical education was, for me, pure pleasure - to the extent that anyone watching me reading it for the first time might have concluded from my enthusiastic nods, smiles and 
'yesses' that I was in need of psychiatric help (Evans, 2003, this issue).

Evans reminds us that every clinical contact is an encounter, and a two-way one at that. He also unravels the personal as well as the physical nature of such examinations or encounters, and offers us the memorable notion of patients being 'meat with a point of view'. Wide reading, he argues, is one way of learning to remember the point of view as well as the meat. He might perhaps have added that literature is also one of the best windows into other peoples' subjective experience, into their consciousness. This function of literature (which is perhaps of particular relevance to psychiatrists) is beautifully explored in David Lodge's most recent novel, Thinks (Lodge, 2001).

Evans invokes Tomorrow's Doctors, the General Medical Council's (then) radical reformulation of how medical education should be delivered (General Medical Council, 1993). This has of course recently been revised (General Medical Council, 2002). The new Tomorrow's Doctors is even more explicit in emphasising that medical education is about active learning rather than teaching, and states that such education must be intellectually challenging. In our brave new world, medical students should be able to identify their own learning needs, and reflect on their practice and that of the doctors they observe. They must also be able to 'understand the social and cultural environment in which medicine is practised'. In this context, the critical reading of world fiction is surely central to the learning of medicine. Assessing how widely prospective medical students have read, and how they have responded to the literature they cite, is thus clearly a legitimate element in medical student selection.

The General Medical Council also now clarifies that not only must a substantial proportion of each medical school's curriculum consist of optional 'special study components', but that a third of these SSCs can be in subjects not directly related to medicine. The opportunities for collaborations between departments of medicine and of literature are suddenly far greater than ever before.

Evans's focus throughout his article is on undergraduate education. We should not forget, however, that such education is merely the first step in a career of lifelong learning. Wide critical reading is equally legitimate as an element of continuing professional development. Reading his article has certainly served as good CPD for me. In this context, it is appropriate and noteworthy that the article does not carry the knowledge-focused multiple choice questions that are a hallmark of APT. Far better to be encouraged to reflect on Evans's argument. In this context, my commentary can be seen as the sort of 'reflective note' that other Royal Colleges encourage as a crucial component of the active CPD process.

Evans has given us a spirited and persuasive defence of the benefits of wide reading to clinical practice. He has also done far more that that. He has tried - and I think succeeded - to summarise the essence of medical education as a whole. He argues that, far from being just about the bioscientific understanding of illness, it is also about embryo doctors enlarging their world view, developing their communication skills, exploring their own values and above all acquiring and maintaining 'a sense of wonder at embodied human nature' and thereby 'recognising the medical privilege of intervening in frail human flesh and experience'. To this, I would add appreciation of the family dimension of health and illness, and of the need to come to terms with personal mortality as well as with that of patients what de Botton (2002: pp. 157-179) calls the sense of 'dust postponed'. Nonetheless, I for one am grateful indeed for so lucid an articulation of how lucky we are to be doctors and, particularly, to be psychiatrists.

\section{References}

De Botton, A. (2002) The Art of Travel. London: Hamish Hamilton.

Evans, M. (2003) Roles for literature in medical education. Advances in Psychiatric Treatment, 9, 380-385.

General Medical Council (1993) Tomorrow's Doctors: recommendations on undergraduate medical education. London: GMC.

- (2002) Tomorrow's Doctors: Recommendations on Undergraduate Medical Education (Revised). London: GMC. Lodge, D. (2001) Thinks. London: Penguin Books.

Cornelius Katona Dean, Kent Institute of Medicine and Health Sciences, University of Kent at Canterbury, Canterbury CT2 7PD, UK (e-mail: c.katona@kent.ac.uk). 